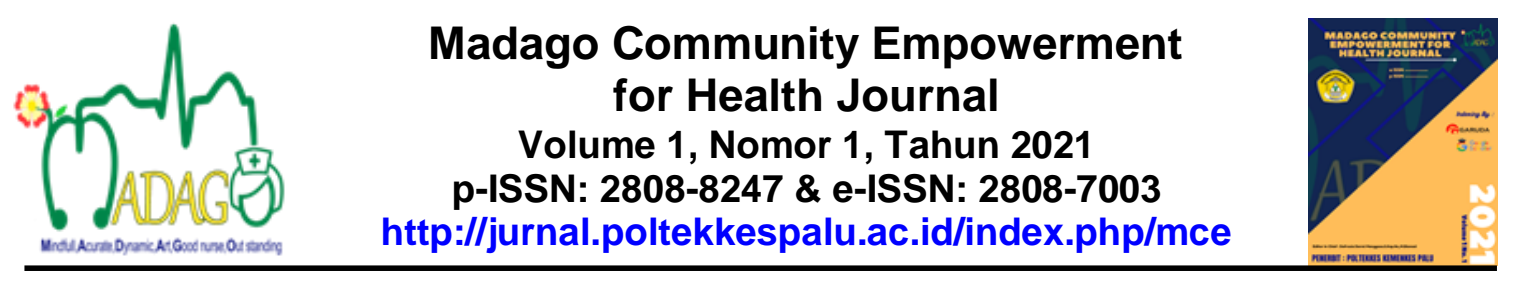

\title{
Upaya Pencegahan Luka Tekan pada Keluarga dengan Anggota Keluarga Mengalami Immobilisasi
}

\section{Prevention of Pressure Ulcer in Family and Patients With Immobilization}

\author{
Dewi Nurviana Suharto $D \square$, Dafrosia Darmi Manggasa \\ Program Studi D-III Keperawatan Poso, Poltekkes Kemenkes Palu \\ Email : dewinurviana.suharto@gmail.com
}

\begin{abstract}
ABSTRAK
Luka tekan merupakan masalah yang sangat serius terutama bagi pasien yang mengalami immobilisasi. Adanya luka tekan mengganggu proses pemulihan pasien, dan menjadi penanda buruk prognosis secara keseluruhan. Upaya pencegahan terjadinya luka tekan dilakukan sedini mungkin sejak pasien teridentifikasi berisiko mengalami luka tekan. Perawatan kulit, yaitu menjaga hidrasi kulit (tidak terlalu lembab atau kering). Salah satu intervensi dalam menjaga integritas kulit adalah dengan cara melindungi kulit dari paparan kelembaban yang berlebihan dengan memberikan topical untuk mengurangi risiko kerusakan tekanan seperti minyak Virgin Coconut Oil (VCO). Tujuan kegiatan pegabdian kepada masyarakat yaitu meningkatkan pengetahuan dan keterampilan keluarga dalam melakukan perawatan secara mandiri untuk mencegah terjadinya luka tekan pada anggota keluarga dengan immobilisasi. Metode pengabdian masyarakat dengan memberikan edukasi tentang upaya pencegahan luka tekan, demonstrasi pengkajian dan perawatan kulit menggunakan VCO. Hasil pengabdian menunjukkan bahwa setelah dari 30 peserta pengabdian terdapat 20 orang dengan pengetahuan baik tentang upaya pencegahan luka tekan. Pengetahuan tentang Upaya pencegahan luka tekan dapat memandirikan keluarga dalam melakukan perawatan pada anggota keluarga dengan immobilisasi.
\end{abstract}

Kata Kunci: immobilisasi, keluarga, pencegahan luka tekan.

\begin{abstract}
Pressure sores are a very serious problem, especially for patients who are immobilized. The presence of pressure sores interferes with the patient's recovery process and is a poor marker of the overall prognosis. Efforts to prevent pressure sores are carried out as early as possible since the patient is identified as being at risk of developing pressure sores. The skin care, namely maintaining skin hydration (not too moist or dry). One of the interventions in maintaining skin integrity is to protect the skin from exposure to excessive moisture by applying a topical to reduce the risk of pressure damage such as Virgin Coconut Oil (VCO). The purpose of community service activities is to increase the knowledge and skills of families in performing care independently to prevent pressure sores on family members by immobilizing them. Community service methods by providing education about pressure sores prevention efforts, demonstrations of assessment, and skincare using VCO. The results of the service showed that after 30 service participants there were 20 people with good knowledge about pressure sores prevention efforts. Knowledge of pressure sores prevention efforts can make families independent in caring for family members by immobilizing.
\end{abstract}

Keywords: Immobilized, family, prevent pressure ulcer

Copyright (c) 2021

DOI: http://doi.org/10.33860/mce.v1i1.655

Received: 12-09-2021; Accepted: 28-10-2021; Published: 28-10-2021 


\section{PENDAHULUAN}

Luka tekan merupakan cedera yang diakibatkan tekanan, gesekan, maupun kombinasi tekanan dan regangan pada area tulang yang menonjol (bony prominence) (Handayani, Irawaty, \& Panjaitan, 2011). Luka tekan menjadi masalah yang sangat serius terutama pada pasien dengan keterbatasan aktifitas atau immobilisasi, kondisi tersebut secara langsung dapat menurunkan angka ksembuhan dan meningkatkan terjadinya komplikasi serta menurunkan kualitas hidup pasien (Alimansur \& Santoso, 2021).

Kejadian luka tekan hampir seluruhnya terdapat di area perawatan. Di area perawatan akut dari $0,4 \%-38 \%$, perawatan jangka panjang dari 2,2\% - 39,4 \%, dan perawatan di rumah 0\% - 17\%. Kejadian luka tekan di seluruh dunia di Intensive care unit (ICU) berkisar 1\% - 56\%. Selanjutnya, Laporan mutu RSUD Poso Tahun 2017 menunjukkan rata-rata angka kejadian luka tekan periode Januari - Desember 2017 sebesar 41 kasus (37,2\%) pada pasien yang imobilisasi (Rekam Medis RSUD Poso, 2017). Proses pemulihan pasien akan terganggu dengan adanya luka tekan, selain itu bisa muncul komplikasi nyeri dan infeksi yang dapat menambah Panjang masa pemulihan pasien. Menurut Rahman et al (2014) luka tekan merupakan penanda buruknya prognosis secara keseluruhan dan menjadi salah satu factor yang berkontribusi terhadap mortalitas pasien terutama pada pasien dengan immobilisasi (Rahman, Alriwani, Assaf, \& Saleh, 2014).

Immobilisasi merupakan keterbatasan individu dalam melakukan aktivitas seperti berganti posisi atau pasien yang mengalami tirah baring selama lebih dari 3 hari yang ditandai dengan gerak anatomis terbatas yang disebabkan oleh perubahan fungsi karena penyakit yang diderita (Guyton, A. C, Hall, 2014). Untuk pasien yang mengalami immobilisasi dengan risiko luka tekan maka upaya pencegahan terjadinya luka tekan harus dilakukan sedini mungkin. Pencegahan dan penanganan dini luka tekan bertujuan untuk mengidentifikasi risiko terjadinya luka tekan dan menciptakan lingkungan yang mendukung pencegahan (Rajamohan et al, 2010). Menurut Wasliyah (2018) kejadian luka tekan dapat dicegah dengan perbaikan nutrisi, mengkaji factor risiko luka tekan, dukungan permukaan, perubahan posisi dan edukasi pencegahan (Wasliyah, 2018).

Dukungan nutrisi dapat meliputi asupan karbohidrat sebagai sumber energi, protein, mitamin dan mineral serta asuhan cairan yang adekuat. Pengkajian factor risiko dapat dilakukan dengan cara mengkaji permukaan kulit terutama kulit diatas tonjolan tulang dengan menggunakan metode head to toe. Perubahan posisi yang baik dalam mencegahn luka tekan yaitu yang dilakukan setiap 2 jam sekali secara terus menerus. Dukungan permukaan yaitu dengan pemberian alas tempat tidur yang sesuai seperti matras decubitus atau menggunakan bahan yang mampu menyerap keringat, tidak ada lipatan alat tempat tidur dan perlu untuk mengganti jika sudah lembab. Edukasi juga merupakan bagian dari factor pendukung dalam mencegah luka tekan, dengan memberikan pengetahuan pada keluarga tentang 
pencegahan luka tekan dapat membantu keluarga dalam merawat pasien (Sumah, 2020).

Keluarga merupakan orang terdekat pasien yang diharapkan memiliki pengetahuan tentang upaya pencegahan luka tekan. Pengetahuan yang baik tentang pencegahan luka tekan dapat membantu memandirikan keluarga dalam merawat anggota keluarga yang mengalami immobilisasi dan dapat meningkatkan pemulihan serta meningkatkan kualitas hidup pasien (Sulidah \& Susilowati, 2017). Salah satu cara yang dapat diajarkan pada keluarga dalam pencegahan luka tekan adalah perawatan kulit, yang terdiri dari: 1) merawat kulit agar tetap terjaga kelembapannya, bersih dan tidak kering, car aini dapat dilakukan dengan menggunkan sabun pembersih dengan $\mathrm{PH}$ yang seimbang, 2) melindungi kulit dari paparan kelembaban yang berlebihan yaitu dengan memberikan topical terapi yang tepat seperti Virgin Cocunut Oil (VCO) (Wasliyah, 2018).

Faktor lain untuk mencegah luka tekan adalah pengetahuan. Pengetahuan dapat membantu seseorang dalam mengambil keputusan terutama keputusan dalam merawat anggota keluarga dengan immobilisasi (Sunaryanti, 2015). Perawatan pasien dengan immobilisasi merupakan perawatan yang berkesinambungan dan membutuhkan waktu yang lama, sehingga pengetahuan tentang pencegahan luka tekan menjadi aspek penting untuk pasien dan keluarga (Alimansur \& Santoso, 2021). Keluarga merupakan orang terdekat pasien yang bertugas dalam memelihara Kesehatan anggota keluarganya serta pemeliharaan sumber-sumber yang ada dalam keluarga (Syapitri, Siregar, \& Ginting, 2017). Untuk itu edukasi tentang pencegahan decubitus penting dilakukan selama pasien dirawat oleh keluarga untuk memandirikan keluarga dalam merawat pasien di rumah karena ketika pasien pulang peran perawatan untuk mencegah luka tekan menjadi tugas keluarga. Penelitian yang dilakukan oleh Rahman et al (2014) menunjukkan bahwa pengetahuan keluarga tentang pencegahan decubitus memiliki kaitan yang erat terhadap kejadian luka tekan selama perawatan di rumah (Rahman et al., 2014).

Desa lantojaya merupakan salah satu Desa yang terletak di Pesisir Pantai Kabupaten Poso Sulawesi Tengah. Masalah yang diidentifikasi di Desa Lantojaya adalah terdapat 12 orang yang mengalami immobilisasi yaitu 10 orang anggota keluarga dalam masa pemulihan pasca stroke, 2 orang anggota keluarga dengan ulkus diabetic. Berdasarkan hasil wawancara diketahui keluarga tidak mengetahui tentang upaya pencegahan luka tekan pada anggota keluarga yang mengalami immobilisasi, beberapa orang hanya melakukan perubahan posisi namun tidak rutin, dan keluarga yang lain melakukan pijatan menggunakan minyak urut di area kaki pasien. Untuk itu kegiatan pengabdian masyarakat ini diperlukan dalam rangka meningkatkan pengetahuan keluarga dengan memberikan edukasi tentang "upaya pencegahan luka tekan pada keluarga dengan anggota keluarga yang mengalami immobilisasi di Desa Lantojaya" 


\section{METODE PELAKSANAAN}

Metode : metode pengabdian yang dilakukan dalam kegiatan ini yaitu : a) Melakukan pengkajian Risiko luka tekan pada anggota keluarga dengan immobilisasi menggunakan alat ukur braden scale, kegiatan ini bertujuan untuk mengidentifikasi risiko luka tekan pada anggota keluarga, b) Edukasi dan Diskusi, Kegiatan ini dilakukan untuk memberikan pemahaman peserta tentang upaya pencegahan luka tekan yang dapat dilakukan pada anggota keluarga dengan immobilisasi, c) Demonstrasi, kegiatan ini bertujuan untuk meningkatkan pengetahuan dan keterampilan keluraga dalam melakukan upaya pencegahan terjadinya luka tekan.

\section{HASIL DAN PEMBAHASAN}

Hasil pengabdian kepada masyarakat dapat digambarkan sebagai berikut :

1. Melakukan pengkajian Risiko Luka Tekan

Kegiatan ini dilakukan dengan cara melakukan pemeriksaan risiko luka tekan menggunakan alat ukur braden scale. Tujuan pemeriksaan ini yaitu untuk mengidentifikasi terjadinya luka tekan. Pemeriksaan ini terdiri dari 6 item penilaian yang terdiri dari persepsi sensori, kelembapan, aktivitas, mobilitas, nutrisi serta friksi dan gesekan. Tujuan utama dari pasien meliputi menghilangkan tekanan, perbaikan mobilitas, perbaikan persepsi sensoris, memperbaiki perfusi jaringan, meningkatkan status nutrisi, meminimalkan gaya tarikan dan friksi (Potter \& Perry, 2010). Meningkatkan kemampuan sensori dan kognitif meningkat: menunjukkan perbaikan tingkat kesadaran. Mempertahankan kulit tetap kering dan bersih: menggunakan losion untuk menjaga agar kulit tetap terlumasi. Mencapai status nutrisi yang adekuat. Menghindari friksi: mengangkat tubuh dan bukan menggeser, menghindari posisi semi fowler (Deprez, Brusseau, Fromageau, Cloutier, \& Basset, 2011). Hasil pemeriksaan resiko luka tekan adalah sebagai berikut :

Tabel 1. Gambaran Risiko Luka Tekan Pada Anggota Keluarga di Desa Lantojaya

\begin{tabular}{clcc}
\hline No. & Hasil Pemeriksaan & Frekuensi & Persentase (\%) \\
\hline 1 & Beresiko & 9 & 75 \\
2 & Resiko sedang & 3 & 25 \\
3 & Beresiko tinggi & - & \\
4 & Resiko yang sangat tinggi & - & $\mathbf{1 0 0}$ \\
\hline \multicolumn{2}{c}{ Jumlah }
\end{tabular}

Sumber Data Primer, 2020

Tabel 1 menunjukkan bahwa dari 12 orang yang mengalami immobilisasi terdapat 9 orang dengan resiko ringan (75\%) dan 3 orang dengan resiko sedang (25\%).

2. Edukasi dan diskusi

Kegiatan dilakukan dengan memberikan penyuluhan tentang pengertian luka tekan, penyebab luka tekan, pencegahan luka tekan dan perawatan luka tekan. Tujuan kegiatan ini adalah untuk meningkatkan pengetahuan tentang pencegahan luka Target Luaran yang dicapai peserta yang mengikuti kegiatan 
ini berjumlah 30 orang, peserta dapat mempresentasikan kembali materi yang telah dijelaskan, peserta dapat menjawab pertanyaan yang diberikan oleh tim pengabdian.

Tabel 2 . Gambaran pengetahuan Keluarga tentang Upaya Pencegahan Luka Tekan di Desa Lantojaya setelah dilakukan edukasi

\begin{tabular}{clccc}
\hline No. & Hasil Pemeriksaan & Frekuensi & Persentase (\%) \\
\hline 1 & Baik & 20 & 66,7 \\
2 & Cukup & 8 & 26,7 \\
3 & Kurang & 2 & 6,6 \\
\hline \multicolumn{2}{r}{ Jumlah } & $\mathbf{3 0}$ & $\mathbf{1 0 0}$ \\
\hline
\end{tabular}

Sumber Data Primer, 2020

Tabel 2 menunjukkan bahwa dari 30 peserta pengabdian menunjukkan bahwa setelah diberikan edukasi pencegahan luka tekan didapatkan 20 peserta memilki pengetahuan baik $(66,7 \%), 8$ peserta memiliki pengetahuan cukup $(26,7 \%)$ dan 2 orang memiliki pengetahuan kurang $(6,6 \%)$.
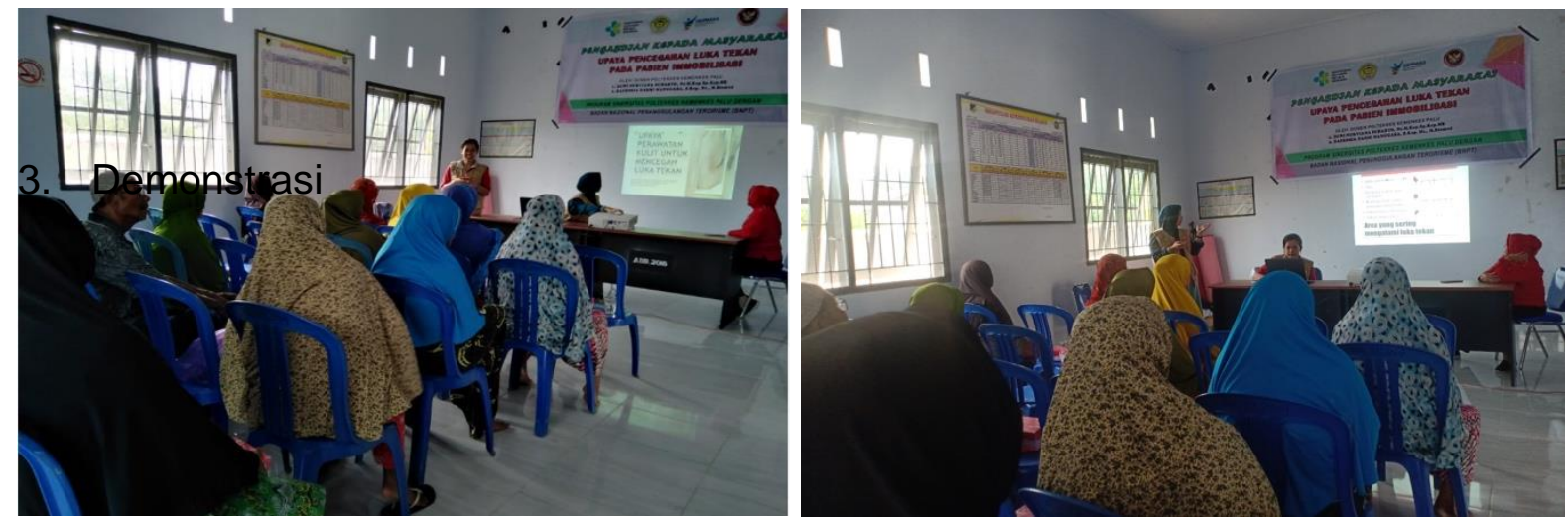

Gambar 1. Edukasi Pencegahan Luka Tekan

3. Demonstrasi

Kegiatan selanjutnya yaitu melakukan demonstrasi tentang prosedur perawatan kulit dan pencegahan luka tekan yang benar. Demonstrasi dilakukan disertai dengan penjelasan prosedur perawatan kulit dan pencegahan decubitus. Selanjutnya peserta melakukan sendiri dengan didampingi oleh fasilitator. Pelaksanaan perawatan kulit dilakukan dengan langkah-langkah sebagai berikut : Hindari menggosok kulit dan bagian yang luka/cedera terlalu keras saat mandi, menggunakan topical terapi yang dapat melembabkan dan melindungi kulit seperti $\mathrm{VCO}$, mempertahan permukaan kulit tetap bersih dan kering Gunakan alas tempat tidur yang dapat menyerap menyerap kelembapan, gunakan alas pada bokong saat posisi miring dan pada area yang bersentuhan dengan ranjang (umumnya area bokong, tulang ekor, tumit, dan betis), hindari menyeret pasien saat merubah posisi (misalnya dari tempat tidur ke kursi roda) karena hal ini dapat menimbulkan luka pada permukaan kulit, mengubah posisi 
setiap 1-2 jam untuk mengurangi tekanan atau gesekan pada satu bagian saja,

Tetap kontrol ke dokter secara berkala untuk perawatan lebih lanjut.
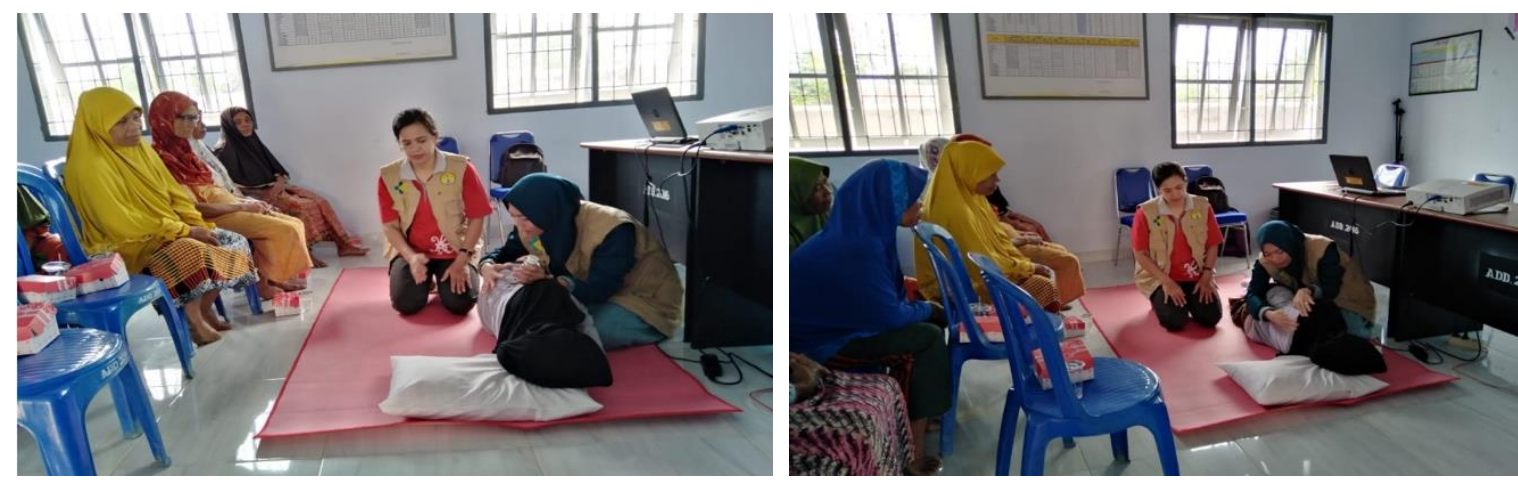

Gambar 2. Demonstrasi Cara Pencegahan Luka Tekan

\section{SIMPULAN DAN SARAN}

Hasil kegiatan pengabdian masyarakat tentang upaya pencegahan luka tekan menunjukkan semua peserta mampu melakukan upaya pencegahan luka tekan secara mandiri. Pengabdi memberikan saran kepada petugas Kesehatan agar dapat memberikan edukasi tentang perawatan untuk pencegahan luka tekan terutama pada keluarga yang memiliki anggota keluarga yang mengalami immobilisasi.

\section{DAFTAR PUSTAKA}

Alimansur, M., \& Santoso, P. (2021). Pendidikan Kesehatan, Mobilisasi dan Deteksi Dini Resiko Dekubitus dalam Pencegahan Kejadian Dikubitus pada Pasien Strok. Jurnal IImiah Permas: Jurnal IImiah STIKES Kendal, 11(1), 177-184. Retrieved from http://stikeskendal.ac.id/journal/index.php/PSKM/article/view/985

Deprez, J.-F., Brusseau, E., Fromageau, J., Cloutier, G., \& Basset, O. (2011). On the potential of ultrasound elastography for pressure ulcer early detection. Medical Physics, 38(4), 1943-1950. https://doi.org/10.1118/1.3560421

Guyton, A. C, Hall, J. E. (2014). Buku Ajar Fisiologi Kedokteran (12th ed.). Jakarta: EGC.

Handayani, R. S., Irawaty, D., \& Panjaitan, R. U. (2011). Pencegahan Luka Tekan Melalui Pijat Menggunakan Virgin Coconut Oil. Jurnal Keperawatan Indonesia, 14(3), 141-148. https://doi.org/10.7454/jki.v14i3.60

Potter, P. A., \& Perry, A. G. (2010). Fundamental Of Nursing: Consept, Proses and Practice (7th ed.). Jakarta: EGC.

Rahman, M. suleman A., Alriwani, R. F. A. R., Assaf, R. M. Al, \& Saleh, M. Y. N. (2014). Exploring Nurses' Knowledge and Perceived Barriers to Carry Out Pressure Ulcer Prevention and Treatment, Documentation, and Risk Assessment Royal Medical Services The University of Jordan. American International Journal of Contemporary Research, 4(4), 112-119. http://www.aijcrnet.com/journals/Vol_4_No_4_April_2014/15.pdf 
Sulidah, \& Susilowati. (2017). Pengaruh Tindakan Pencegahan Terhadap Kejadian Dekubitus Pada Lansia Imobilisasi. Jurnal IImiah IImu-IImu Kesehatan, 15(3), 166-170. http://jurnalnasional.ump.ac.id/index.php/medisains/article/view/2081

Sumah, D. F. (2020). Keberhasilan Penggunaan Virgin Coconut Oil secara Topikal untuk Pencegahan Luka Tekan (Dekubitus) Pasien Stroke di Rumah Sakit Sumber Hidup Ambon. Jurnal Kedokteran Dan Kesehatan, 16(2), 93-102. Retrieved from https://jurnal.umj.ac.id/index.php/JKK

Sunaryanti, B. (2015). Prevention At Pressure Sores With Reposition Health Education and Coconut Oil. PROFESI, 1(September 2014), 58-64. https://media.neliti.com/media/publications/162190-ID-none.pdf

Syapitri, H., Siregar, L. M., \& Ginting, D. (2017). Metode Pencegahan Luka Decubitus Pada Pasien Bedrest Total Melalui Perawatan Kulit. Idea Nursing Journal, 8(2), 15-22. https://doi.org/10.52199/idea.v8i2.8827

Wasliyah, S. (2018). Efektivitas Penggunaan Virgin Coconut Oil (Vco) Dan Minyak Zaitun Untuk Pencegahan Luka Tekan Grade I Pada Pasien Yang Berisiko Mengalami Luka Tekan Di Rsu Kabupaten Tangerang. Jurnal Medikes (Media Informasi Kesehatan), 5(2), 192-205. https://doi.org/10.36743/medikes.v5i2.60 